\title{
Edwin Seligman, initiator of global progressive public finance*
}

\author{
Madeline Woker \\ Columbia University, Department of History, 413 Fayerweather Hall, 1180 Amsterdam Avenue, \\ MC 2527, New York, NY 10027, USA \\ E-mail: mw2981@columbia.edu
}

\begin{abstract}
This article surveys the global acquaintances of Edwin Robert Anderson Seligman, a worldrenowned authority on progressive public finance and professor of political economy at Columbia University between 1885 and 1933. Through his published writings, networks, and internationalist efforts, Seligman extended an emerging theory of progressive taxation to an international arena. This empowered his students, especially his Asian students, to build an analysis of the limitations of imperial political accountability and suggest bold financial reform. These links are uncovered for the first time and reveal Seligman's place in the intellectual and political history of tax reform in American and European formal and informal empires. Consequently, the article also sheds new light on the history of what the legal historian Ajay Mehrotra has called the 'early Columbia school of taxation and economic development'.
\end{abstract}

Keywords China, global, India, Seligman, progressive, public finance

'A new scale of values is being set up everywhere', wrote Gyan Chand in 1928, and the 'fact cannot but have far-reaching reactions on the fiscal institutions of the world'. ${ }^{1}$ As professor of economics at Patna University (Bihar province, British India), he saw this worldwide movement as clearly applicable to the colonial world. A specialist in public finance, Chand was a strong believer in taxation's role in development, and he sought to instil a 'positive attitude towards taxation' in his compatriots. This positive attitude entailed a generous vision of the role of the state, a belief in its redistributive virtue, and a more cooperative approach to fiscal obligation and citizenship. The need for 'fiscal reconstruction' along these lines became an important issue in the aftermath of the First World War, notably because of the dramatic expansion of public expenditure generated by the conflict and by new political reforms in the non-Western world.

I would like to thank Susan Pedersen, Emmanuelle Saada, the editors of the Journal of Global History, and the two anonymous reviewers for their very useful comments on earlier versions of this article.

1 Gyan Chand, Some aspects of fiscal reconstruction in India: being the Banailli readership lectures in Indian economics, Patna University, 1927-1928, Oxford: Oxford University Press, 1931, p. 1. 
This re-evaluation of the role of taxation was rooted in earlier reflections about the nature of modern fiscal power that date back to the early 1890s. The idea that taxes should be socially transformative thanks to a more comprehensive individual assessment of income and wealth, as well as the introduction of progressive rates, had been hotly debated before 1914, and came to the fore more intensively during the interwar period. Edwin Robert Anderson Seligman, a Columbia professor and internationally acclaimed tax expert, played a significant role in spreading these new ideas about taxation.

Seligman's 'catholicity of interest, together with an exceptional erudition and a broad acquaintance with scholars of many countries' placed him at the centre of an international network of academics, politicians, foundations, and international organizations that greatly relied on his expertise. ${ }^{2}$ Many well-known public finance economists, including Chand, knew him personally, corresponded with him, or simply read his works, and made specific use of his ideas by adapting them to specific non-Western circumstances. Indeed, for more than fifty years, Seligman developed his standing as an initiator of progressive public finance by spreading knowledge about taxation throughout a rich global network of public finance scholars.

The historians Nicolas Delalande and Ajay Mehrotra have already underlined the significance of Edwin Seligman's work. Ajay Mehrotra wrote extensively about Seligman's role in the making of the US income tax and his status as a national tax expert in the late nineteenth and early twentieth centuries. ${ }^{3}$ Nicolas Delalande uncovered Seligman's links with European scholars, especially French public finance economists, and emphasized his role as an international tax expert. ${ }^{4}$ This article proposes to go further and recover Seligman's global dimension by exploring his links with Asia, principally China, India, and Japan, but also his engagement with American imperial ventures, notably in Cuba. The true scope of his non- Western network has hitherto remained largely unsuspected, and the time has come for a more connected history of American progressive public finance, in line with recent efforts to 'decentre' American history. ${ }^{5}$ Most importantly, however, this article will analyse how Seligman's non-Western students read his writings on fiscal issues. They were particularly eager to prepare a fiscally autonomous national future, where control of the public purse would go hand in hand with self-government. Financial questions were considered to be part and parcel of a necessary political education for the citizens of a future 'free state'. ${ }^{6}$ A first step was to demonstrate that

2 Carl S. Shoup, 'Seligman, Edwin R. A.' in International encyclopaedia of the social sciences, New York: Macmillan and Co., 1968, p. 1968.

3 Ajay Mehrotra, Making the modern American fiscal state: law, politics, and the rise of progressive taxation, 1877-1929, New York: Cambridge University Press, 2013; Ajay Mehrotra, 'From Seligman to Shoup: the early Columbia school of taxation and development', in W. Elliott Brownlee, Eisaku Ide, and Yasunori Fukagai, eds, The political economy of transnational tax reform: the Shoup mission to Japan in historical context, Cambridge: Cambridge University Press, 2013, pp. 30-54.

4 Nicolas Delalande, Les batailles de l'impôt: consentement et résistances de 1789 à nos jours, Paris: Seuil, 2011, pp. 168-9; Noclas Delalande, 'Edwin R. A. Seligman et le moment progressiste des finances publiques (fin du XIXe siècle-années 1930)', in Martine Kaluszynski and Renaud Payre, eds., Les savoirs de gouvernement, Paris: Economica, 2013, pp. 71-85.

5 See Ian Tyrell, 'Reflections on the transnational turn in United States history: theory and practice', Journal of Global History, 4, 3, 2009, pp. 453-74.

6 See Gyan Chand, The financial system of India, with a foreword by Edward Hilton Young, London: K. Paul, Trench, Trubner and Co., 1926, p. 4. 
'oriental people' were as fit as their Western counterparts to be subjects of modern taxation, especially income tax. ${ }^{7}$

Between the late 1880s and the 1930s, taxation policies underwent dramatic changes, and the clearest manifestation of fiscal modernity, according to Seligman, was income tax. Whereas older taxation systems had been much more reliant on indirect taxes 'paid without the contributors being really conscious of it', modern taxation required 'a far greater sense of civic obligation' because taxpayers were now expected to readily 'contribute their share to the common burden'. ${ }^{8}$ Seligman saw these developments as the culmination of a long history marked by successive stages of fiscal development. The opening chapter of his Essays in taxation provides a teleological reading of the history of taxation which traces an evolution from 'primitive' uniform poll taxes to the modern income tax. ${ }^{9}$

The late nineteenth and early twentieth centuries represented the culmination of this logic, and in the 1914 edition of his landmark book on the topic, Seligman could claim that 'everywhere, in short, there seems to be a trend toward the income tax'. ${ }^{10}$ However, while the implementation of a progressive income tax was firmly on the agenda in much of Europe and North America, fiscal ideas travelled much less easily between European metropoles and their formal and informal empires. Colonial investors, European settlers, and wealthy local elites did not welcome these new calls for fiscal modernity as they dealt a direct blow to their fiscal privileges. A common argument was that fiscal reform was impossible because of the so-called fiscal 'immaturity' of the native population. Furthermore, modern personal taxation was not only too costly; it also disturbed the status quo and could eventually lead to political unrest. ${ }^{11}$

Colonial budgets were mainly fed by customs duties levied on cash crops produced for international markets but also by personal taxes, which were considered highly disruptive of native economic life because they forced indigenous populations into a modern waged labour economy and led to the monetization of colonial economies. African colonies have received the greatest scholarly attention, with works using Marxist and Foucauldian frameworks and, more recently, quantitative evidence. ${ }^{12}$ Specialists in economic history have been at the forefront of this upsurge of interest, especially in Africa and Southeast Asia. ${ }^{13}$

7 See, for instance, Shankar Madhav Pagar, The Indian income tax: its history, theory and practice, Baroda: the author, 1920, p. 209; or J. P. Niyogi, The evolution of the Indian income tax, London: P. S. King, 1929, p. 149.

8 E. R. A. Seligman, Essays in taxation, New York: Macmillan and Co., 1925, p. 4.

9 E. R. A. Seligman, 'The development of taxation', in Essays in taxation, pp. 1-18.

10 E. R. A. Seligman, The income tax, New York: Macmillan and Co., 1914, p. 3.

11 See, for instance, David Todd, 'The impôts arabes: French imperialism and land taxation in colonial Algeria, 1830-1919', in John Tiley, ed., Studies in tax law, vol. 3, London: Hart Publishing, 2009, pp. 113-38. See also Madeline Woker, 'Empire of inequality: the politics of taxation in the French colonial empire, 19181939', PhD thesis, Columbia University, in progress; Madeline Woker, 'Empire, taxes, and loopholes: taxation and colonial capitalism in the French empire, 1920s-1950s', unpublished working paper.

12 See, for example, Barbara Bush and Josephine Maltby, 'Taxation in West Africa: transforming the colonial subject into the governable person', Critical Perspectives on Accounting, 15, 2004, pp. 5-34; Matthew Forstater, 'Taxation and primitive accumulation: the case of colonial Africa', Research in Political Economy, 22, 2005, pp. 51-65; Mahmood Mamdani, Citizen and subject: contemporary Africa and the legacy of late colonialism, Princeton, NJ: Princeton University Press, 1996, pp. 54-9.

13 Anne Booth, 'The burden of taxation in colonial Indonesia in the twentieth century', Journal of Southeast Asian Studies, 11, 1, 1980, pp. 91-109; Anne Booth, 'Land taxation in Asia: an overview of the 19th and 20th centuries', Oxford Development Studies, 42, 1, 2014, pp. 1-18; Anne Booth, 'Night watchman, extractive, or developmental states? Some evidence from late colonial south-east Asia', Economic History Review, 60, 2 , 2007, pp. 241-66; Ian Brown, 'Tax remission and tax burden in rural lower Burma during the economic crisis of the early 1930s', Modern Asian Studies, 33, 2, 1999, pp. 383-403; Ewout Frankema, 'Raising revenue in the British empire: how “extractive” were colonial taxes?', Journal of Global History, 5, 3, 2010, pp. 447-77; 
Their works bear the mark of the 2001 article by Daron Acemoglu, Simon Johnson, and James A. Robinson on the 'colonial origins of comparative development', which inaugurated a spate of studies linking the existence of extractive institutions in non-settler colonies (such as taxation) to smaller future development prospects. ${ }^{14}$ Ewout Frankema has critiqued this hypothesis in his recent attempt to evaluate tax levels in British non-settlers' colonies. In a book published in 2014, Leigh Gardner also wrote extensively about the 'problem of colonial taxation' in colonial Kenya and Northern Rhodesia, using taxation as a lens to explain the 'resource constraints' of colonial polities, their role in shaping colonial economies, and their effects on long-term economic development. Anne Booth and Ian Brown, of the School of Oriental and African Studies, have published studies of taxation in colonial Southeast Asia. Although originally a specialist of Indonesia, Booth's most recent articles have followed a comparative approach and have used taxation to understand the nature of colonial states. Brown has focused on colonial Burma and especially on tax policies during the interwar economic crisis.

The fiscal control exerted by Western powers over what Robinson and Gallagher have called their 'informal empire' has drawn more attention. ${ }^{15}$ Debt imperialism in the late nineteenth and early twentieth centuries entailed the custody and control of tax revenues because they served as a guarantee for the disbursement of foreign loans. In China, the most important fiscal administrations, such as the Salt Inspectorate or the Maritime Customs Revenue Office, were indeed completely or partly in foreign hands. ${ }^{16}$ In the turbulent early years of republican China, fiscal issues were thus a major topic of national politics. A number of Chinese scholars consequently began to write works advocating fiscal independence, modern fiscal techniques, and a reasoned distribution of fiscal responsibilities among different government levels. Some of Seligman's students - Shou Jingwei, for instance - were genuine fiscal sociologists who understood that taxation was about much more than revenue and in fact intimately linked to the political system. ${ }^{17}$

A careful consideration of the doctoral dissertations and pamphlets written by Seligman's students shows that his guidance played no small role in encouraging a generation of Columbia-trained scholars to envisage the end of Western imperial fiscal domination, even if that meant proceeding well beyond the benevolent recommendations of their adviser. Seligman's own published work was in fact rather Western-centric despite some early forays into colonial policy-making and a 1932 report on the fiscal system in Cuba. He seemed to have left it to his students, especially those from China and India, to 'lift the veil' which had 'hitherto

Leigh Gardner, Taxing colonial Africa, Oxford: Oxford University Press, 2014 ; Denis Cogneau, Yannick Dupraz, and Sandrine Mesplé-Somps, 'African states and development in historical perspective: colonial public finances in British and French West Africa', Paris School of Economics working paper, 2016, https:// www.parisschoolofeconomics.eu/docs/cogneau-denis/colonial-public-finance-in-west-africa-cogneaudupraz-mesple-somps.pdf (consulted 25 April 2018).

14 Daron Acemoglu, Simon Johnson, and James A. Robinson, 'The colonial origins of comparative development: an empirical investigation', American Economic Review, 91, 5, 2001, pp. 1369-1401, esp. p. 1375.

15 John Gallagher and Ronald Robinson, 'The imperialism of free trade', Economic History Review, 6, 1, 1953, pp. 1-15.

16 Julia Strauss, 'Rethinking institutional capacity and tax regimes: the case of the Sino-Foreign Salt Inspectorate in republican China', in Deborah Brautigam, Odd-Helge Fjeldstad, and Mick Moore, eds., Taxation and state-building in developing countries, Cambridge: Cambridge University Press, 2008, pp. 212-34; Hans Van de Ven, Breaking with the past: the maritime customs service and the global origins of modernity in China, New York: Columbia University Press, 2014.

17 Shou Jingwei (Kinn Wei Shaw), Democracy and finance in China: a study in the development of fiscal systems and ideals, New York: Columbia University Press, 1926, p. 186. 
concealed the teachings and the motives that have guided fiscal theory and fiscal practice in China' and elsewhere. ${ }^{18}$ Yet his intermittent direct engagement with non-Western fiscal affairs shows that his rather conservative suggestions for American colonies in 1899 transformed into much more radical and transformative calls for change in the early 1930s, notably for Cuba, a client state of the United States. Convinced of the latter's moral obligation to disseminate progressive values to the world, he thought that the 'results of training and education' would soon allow non-Western nations to attain 'economic equality' with Europe and America. ${ }^{19}$ Greater fiscal cooperation and eventual convergence would ensue.

\section{Seligman, progressivism, and public finance}

Edwin Seligman was born in New York City in 1861 to a wealthy family of German-Jewish bankers. His father, Joseph Seligman, had immigrated to the United States from Bavaria in 1837 and rapidly grew to be a prominent financier. The Seligman family soon became highly involved in New York's Jewish community and the city's civic life. Together with his son, Joseph also became closely linked to Felix Adler's Ethical Culture movement and more generally to a certain form of humanistic Judaism. Seligman and his siblings were educated at home by the American author Horatio Alger Jr and, thanks to frequent travels abroad, the young Edwin rapidly became proficient in German, French, Italian, and Russian. ${ }^{20}$ This upbringing placed him in a very distinct community of American Jews of German origin who 'maintained, to some degree, a set of loyalties to the lands, regions, and towns from which they or their parents had hailed'. ${ }^{21}$

Seligman enrolled at Columbia College in 1875 and left for France and Germany after receiving his bachelor's degree. As Daniel Rodgers has shown, study trips to Europe, and especially Germany, were a common feature of American graduate education at the time. ${ }^{22}$ In Heidelberg and Berlin, Seligman studied under the guidance of Karl Knies, Gustav Schmoller, and Adolph Wagner and continued to correspond with them long after his return to the United States. These professors were the leading members of the German Historical School, whose founders spurned the deductive and ahistorical logic of classical economics. By stating the importance of social conditions and historical contingency, Historical School economists largely rebuffed the central tenets of laissez-faire economics and asserted the central role of the state.

Seligman viewed the economy as a set of interrelations between deeply socialized individuals, in which the state ought to play a crucial and active role. He thought that, in civilized society, the state is as necessary to the individual as the air he breathes; unless he reverts to

18 E. R. A. Seligman, preface to Shou, Democracy and finance in China, p. i.

19 E. R. A. Seligman, 'World peace and economic stability', Proceedings of the Academy of Political Science, 13, 2, 1929 , p. 201.

20 Ajay Mehrotra, 'From Berlin to Baltimore: German historicism and the American income tax, 1877-1913', in Alexander Nutzenadel and Christoph Strupp, eds., Taxation, state, and civil society in Germany and the United States from the 18th to the 20th century, Baden-Baden: Nomos, 2007, p. 5; Mehrotra, Making the modern American fiscal state, p. 100.

21 Hasia R. Diner, 'Living locally, organizing nationally, and thinking globally: the view from the United States', in Hasia R. Diner and Gennady Estraikh, eds., 1929: mapping the Jewish world, New York and London: New York University Press, 2013, pp. 11-26.

22 Daniel T. Rodgers, Atlantic crossings: social politics in a progressive age, Princeton, NJ: Princeton University Press, 1998. 
stateless savagery and anarchy he cannot live beyond its confines'. ${ }^{23}$ The modern individual had thus grown increasingly inseparable from a wider group that endowed him or her with new and pressing obligations to his or her fellow citizens. Seligman's German education reinforced this belief in the centrality of the state but also its crucial role in instigating social change. In his discussion of the links between the German Historical School and American Progressivism, Holger Nehring explains that, 'rather than seeing the economy as an organic whole which developed in and of itself', members of these two movements 'regarded it as an entity which could be influenced', and it is precisely this ethic of intervention and public expertise that young American students brought back to the United States. ${ }^{24}$

This ethic soon coalesced into a more concrete historical moment that scholars have called the Progressive Era. ${ }^{25}$ Progressives attempted to respond to the challenges posed by the 'capitalist economy that they both embraced and tried to reform' by devising new solutions to the major economic and social upheavals wrought by industrial development. ${ }^{26}$ These solutions sought to improve individual lives through heightened state intervention but, more concretely, through a set of noteworthy innovations such as protective labour legislation, antitrust regulation, universal suffrage, and a progressive income tax. ${ }^{27}$ Together with his fellow prominent public finance economists, Richard T. Ely and Henry Carter Adams, Edwin Seligman actively advocated the graduated taxation of incomes, profits, and inherited wealth transfers. ${ }^{28}$ Indeed, in the last decade of the nineteenth century, an important intellectual revolution took place in the realm of public finance in America and in Europe. This change was conceptualized in a crucial distinction between the 'benefit theory' and the 'ability to pay theory'.

The 'benefit theory' of taxation is based upon a reciprocal or transactional vision of the relation between the state and the citizen. This theory posits that citizens pay taxes in order to ensure the protection of their goods or the provision of services. The 'ability to pay theory', in contrast, pays much greater heed to economic inequality among taxpayers. It thus emphasizes the notion of 'equal sacrifice' by recognizing that the marginal utility of money decreases as income increases. ${ }^{29}$ The system of progressive taxation that Seligman and other progressive public finance economists sought to put in place was meant to ensure real tax justice by raising the tax rate in close concordance with the tax base. The main justification for this new method of taxation was that it would allow for a fairer allocation of tax burdens but also that it was the modern endpoint of a long fiscal history. Seligman thought that the history of finance showed 'the evolution of the principle of faculty or ability to pay - the principal that each individual should be held to help the state in proportion to his ability to help himself'. ${ }^{30}$

23 Seligman, Essays in taxation, p. 73.

24 Holger Hehring, 'The paradoxes of state-building: transnational expertise and the income tax debates in the United States and Germany, c.1880-1914', in Holger Nehring and Florian Schui, eds., Global debates about taxation, London: Palgrave Macmillan, 2005, p. 102.

25 See, most recently, Christopher McKnight Nichols and Nancy C. Unger, A companion to the Gilded Age and Progressive Era, Hoboken, NJ: John Wiley \& Sons, Inc., 2017.

26 Daniel T. Rodgers, 'Capitalism and politics in the Progressive Era and in ours', Journal of the Gilded Age and Progressive Era, 13, 3, 2014, p. 381.

27 Marianne Johnson, 'Progressivism and academic public finance', History of Political Economy, 46, 1, 2014, p. 3 .

28 See Henry Carter Adams, The science of finance: public expenditure and public revenues, New York: Henry Holt and Company, 1898; Richard T. Ely, Taxation in American states and cities, New York: T. Y. Crowell, 1888; Mehrotra, Making the modern American fiscal state, p. 86.

29 Mehrotra, Making the modern American fiscal state, pp. 96-7.

30 Seligman, Essays in taxation, p. 18. 
This vision of taxation was not widely shared, and opponents of progressive taxation dreaded its 'confiscatory' nature. They began to organize against the reform in the early 1890s and that is also when Seligman embarked on a long and arduous defence of tax progressivity which spawned debate inside and outside the United States. As Marion Fourcade explains, from the 1890s onwards, 'the identity of American economics ... remained firmly located within universities, which alone could endow economists with essential skills, credentials and legitimacy', and Seligman's intense work of public advocacy was indeed exerted from the ivory tower of his Columbia University chair. ${ }^{31}$ Together with his colleague Richard Mayo-Smith, Seligman built the reputation of the Department of Political Economy and Social Science and remained at Columbia until his retirement in $1931 .^{32}$

\section{Seligman and the global dissemination of ideas about taxation}

Through his university connections, Seligman's opinions on taxation were made palatable to a large audience and soon became highly valued by academics, politicians, and lawyers outside the United States. The publication of The shifting and incidence of taxation in 1892, of Progressive taxation in theory and practice in 1894, and of his Essays in taxation in 1895 firmly established Seligman's authority in the field. Faithful to the historical and comparative approach learned in Germany, he actively sought to give to his work a distinctive international and world-historical perspective. According to him,

in some respects the most significant fact of the recent development of economic thought is its growing international character. Not only does the modern economist find it necessary to draw his facts from a wider field than that of his own country; but if he desires to keep abreast of the advances in theory he also finds it incumbent on him to read many languages and note the movements in widely distant countries. In no domain is this more true than in the science of finance. ${ }^{33}$

The dense and numerous bonds that Seligman was able to create with his foreign correspondents helped to bring about a new transnational sphere of expertise. Knowledge about taxation, democracy, and redistribution began to be circulated on an unprecedented scale.

The significance of Seligman's German and French connections and their influence on the making of the American income tax has already been amply treated in recent historical scholarship. ${ }^{34}$ However, further research into his uncatalogued correspondence reveals the diversity of his colleagues. For instance, in 1895, Bela Foldes, a professor of public finance at the University of Budapest, thanked him 'for his most valuable volume on taxation' and later published a much cited volume, classically entitled Finanzwissenschaft, containing numerous

31 Marion Fourcade, Economists and societies: discipline and profession in the United States, Britain, and France, 1890s to 1990s, Princeton, NJ: Princeton University Press, 2009, p. 62.

32 William J. Barber, ed., Economists and higher learning in the nineteenth century, New Brunswick, NJ: Transaction Publishers, 1993, p. 197. Richard Mayo-Smith wrote about immigration and statistics: see, for instance, Emigration and immigration, New York: C. Scribner's Sons, 1890; Statistics and economics, New York: C. Scribner's Sons, 1899.

33 Seligman, Essays in taxation, p. 543, emphasis added.

34 On the German connection, see Mehrotra, 'From Berlin to Baltimore', pp. 167-84; on the French connection, see Delalande, 'Edwin R. A. Seligman', pp. 80-3, and Delalande, Batailles de l'impôt, pp. 168-9. 
references to Seligman's work. ${ }^{35}$ One year later, the Italian economist Ugo Rabbeno began his review of Seligman's Essays in taxation in the Riforma Sociale by stating that 'Professor Seligman' no longer needed to be presented to the readers, given his great reputation. ${ }^{36}$ Giovanni Fasolis, author of a study on double taxation in 1914, wrote to introduce his work to Seligman and addressed him as his 'dear magister'. ${ }^{37}$ Seligman himself greatly admired the Italian scienza delle finanze and thought that the Italians, together with the Dutch, were responsible for the 'best works on certain lines of public finance' ${ }^{38}$ His friendships with Vilfredo Pareto and Maffeo Pantaleoni, the author of a book on tax incidence in 1882 and later recognized as one of the founders of the Italian School of Economics and Finance, lasted a lifetime. ${ }^{39}$

\section{Seligman's global networks}

By the time he had reached the age of thirty-seven, Seligman's work on taxation was already well recognized as applicable not only in the Western environment but beyond. ${ }^{40}$ In 1899 , his reputation and expertise even led the American Economic Association to appoint him, together with Jeremiah W. Jenks, Charles S. Hamlin, and Albert Shaw, to write essays on colonial finance. While the United States was still fighting a war of colonial conquest in the Philippines, this group of economists and lawyers were advising the fledgling American colonial state on how to raise revenue efficiently. ${ }^{41}$ In his essay on the 'French colonial fiscal system', Seligman diligently enumerated revenue sources in all the colonies administered by France in the late nineteenth century and ended with a number of observations and recommendations. In accordance with colonial fiscal practice at the time, he suggested that metropoles should be allowed to become fiscally autonomous and that pre-colonial systems ought not to be jettisoned immediately. ${ }^{42}$ In contrast to later suggestions, the 'Report of the committee on colonies' also recommended retaining the practice of tax farming and the levying of consumption taxes on commodities. ${ }^{43}$

Dubbed an 'imperialist' by the historian Gary Marotta, Seligman indeed wholeheartedly embraced the 'civilizing role' of the United States and sought to contribute to it through the

35 Rare Book and Manuscript Library, Columbia University, Edwin Robert Anderson Seligman Papers (henceforth, ERASP), box C11, Bela Foldes to Seligman, 23 November 1895, box C11.

36 Ugo Rabbeno, review of Essays in taxation in Riforma Sociale, 3, 5, 1896, pp. 307-8.

37 ERASP, box 5A, Giovanni Fasolis to Seligman, 17 April 1915.

38 Seligman, Essays in taxation, p. 561.

39 Mario Baldassari, ed., Maffeo Pantaleoni: at the origin of the Italian School of Economics and Finance, New York: Saint Martin's Press, 1997; E. R. A. Seligman, 'Pareto and Pantaleoni: personal reminiscences of two Italian economists', Political Science Quarterly, 45, 3, 1930, pp. 341-6. See also P. F. Asso, ed., The international spread of Italian economic thought, 1750-1940, Firenze: Polistampa Editori, 2001. On the influence of the Italian School of Public Finance on American academia, see Richard E. Wagner, 'Public choice and the diffusion of classic Italian public finance', Il Pensiero Economico, 11, 2004, pp. 271-82; on the intellectual history of fiscal science more generally, see Jürgen G. Backhaus and Richard E. Wagner, 'From continental public finance to public choice: mapping continuity', History of Political Economy, 37, 2005, pp. 314-32.

40 Notably in Japan: see ERASP, box 3, Hichitaro Hisa to Seligman, 25 May 1898.

41 Gary Marotta, 'The academic mind and the rise of U.S. imperialism: historians and economists as publicists for ideas of colonial expansion', American Journal of Economics and Sociology, 42, 2, 1983, pp. 217-34.

42 E. R. A. Seligman, 'The French colonial fiscal system', Publications of the American Economic Association, 1, 3, 1900, pp. 21-39.

43 Jeremiah W. Jenks, Charles S. Hamlin, Edwin R. A. Seligman, and Albert Shaw, 'Report of the committee on colonies', Publications of the American Economic Association, 1, 3, 1900, pp. 17-20. 
production of scientific knowledge. His indignant response to a radical anti-imperialist speech by John R. Commons at the 1899 annual meeting of the American Economic Association is a case in point. ${ }^{44}$ In an impassioned address, Commons had accused economists of attending to the economic interests of the imperialist ruling class while allowing them to 'govern 10000000 Asiatics without their consent and without giving them a share in our government'. ${ }^{45}$ Seligman's own brother Isaac, a banker whose firm had interests in Latin America, had helped fund the report on colonial finance. ${ }^{46}$ Yet Seligman responded that 'the economist' should 'repudiate with scorn the imputation that he is endeavouring to subserve the special interests of any individual or of any social class'. ${ }^{47}$ Because of his unflinching belief in the superiority of liberal capitalism and the objectivity of the economic expert, Seligman paid little attention to the violent implications of American imperialism.

Seligman, firmly part of the New York elite, was thus no radical. His brother-in-law was George Louis Beer, a prominent historian of British colonial expansion and professor at Columbia, who later briefly became the director of the Mandates Section of the League of Nations secretariat. Seligman and Beer often hosted receptions: in December 1900, for instance, a dinner was given in honour of the Chinese Minister Wu Ting Fang, bringing together eminent financiers and academics. ${ }^{48}$ Seligman was also a privileged interlocutor of high-profile personalities visiting the United States from both China and Japan. Among them was Count Kaneko Kentaro, a senior Japanese official who was sent to the United States in 1904 in order to gain support from President Roosevelt in the Russo-Japanese War.

In 1905, Seligman was set to depart for a year-long trip to the 'Orient' in order to 'study the economic side of colonial administration in Egypt, India, and the other British possessions and the Colonies of Japan' ${ }^{49}$ Friedrich Hirth, then Professor of Chinese at Columbia and a member of the Chinese Maritime Customs service from 1870 to 1897 , wrote numerous introduction letters for Seligman to colleagues and friends in China and Hong Kong. The American Embassy in London also notified Seligman that Lord Lansdowne, the British Secretary of State for Foreign Affairs, had been personally briefed about Seligman's 'proposed visit to East'. ${ }^{50}$ Seligman, his wife, and his mother-in-law were able to go as far as Gibraltar in the summer of 1905, but in the autumn of the same year the couple abruptly lost one their two daughters. The trip was cancelled and no further attempt was made to travel to Asia. Seligman's understanding of colonial government and finance would from then on mainly come from his own readings and his relationships with non-Western students.

These long-distance interactions were facilitated by institutional links as well as by Seligman's intense editorial activities. As Delalande rightly puts it, Seligman was first and foremost a 'man of reviews'. ${ }^{51}$ As the chief editor of the Political Science Quarterly, he was very active in

44 Marotta, 'Academic mind', p. 225.

45 John R. Commons, E. R. A. Seligman, L. M. Keasbey, E. W. Bemis, Professor Mayo-Smith, and Professor Hadley, 'Discussion of the president's address', Publications of the American Economic Association, 1, 1, 1900, p. 73.

46 Edward T. Silva and Sheila Slaughter, Serving power: the making of the academic social science expert, Westport, CT: Greenwood Press, 1984, p. 135.

47 Seligman, 'Discussion of the president's address', p. 84.

48 ERASP, box 3, table plan of the dinner in honour of Wu Ting Fang, Chinese minister, Saturday, 8 December 1900 .

49 ERASP, box 4, letter of introduction for E. R. A. Seligman from Francis B. Loomis, acting Secretary of State, addressed to the diplomatic and consular officers of the United States, 14 June 1905.

50 ERASP, box 4, letter from Delancey Jay, 16 October 1905.

51 Nicolas Delalande, 'E. R. A. Seligman', p. 80. 
requesting papers and interventions for the journal. He also kept close ties with editors at non-American journals such as the Weltwirtschaftliches Archiv, the first journal with an exclusive focus on international economics. Such journals were usually eager either to review Seligman's work or to publish original articles he had authored. ${ }^{52}$ Seligman was later elected foreign correspondent or member of many prestigious academies and associations, such as the Institut de France, the Italian Academia del Lincei, the Russian Academy of Science, the Cuban Academy of Political and Social Science, the British Royal Economic Academy, the French Académie des sciences morales et politiques, the Chinese Political Science Society, and the China Institute in New York. ${ }^{53}$

By the mid 1910s, Seligman's work had become 'so much in fashion' internationally that it seems that no significant fiscal reform could be envisaged without mentioning his work. ${ }^{54}$ In Japan, although the works of Richard T. Ely had apparently arrived earlier, Seligman's influence was decisive in diffusing a belief in the merits of 'modern' fiscal practices. Japanese scholars and politicians began to use a new language of taxation, gradually jettisoning the old reliance on land taxes and extolling the virtues of personal and direct taxation based on the principle of the ability to pay. ${ }^{55}$ Among his students, Seligman counted Masao Kambe, a professor of public finance at Kyoto Imperial University, Yetaro Kinosita, the author of a PhD thesis on Japan's international trade, and Zensaku Sano, who later became president of the Tokyo Commercial School, now known as Hitotsubashi University. ${ }^{56}$ Interestingly, Carl Shoup, selected as leader of the seven-member economic team sent to Japan in 1949 to overhaul the tax system, would benefit from his professor's personal contacts. Indeed, before arriving in Japan, Shoup was already in touch with Matsushita Shutaro, the author of a notable essay on The economic effects of public debts, which was written under the guidance of Seligman and made extensive use of the latter's work on war finance. ${ }^{57}$

Among his Asian students, Seligman also counted a number of Chinese nationals and British Indians to whom he provided extensive pastoral care in addition to intellectual training. In 1909, for instance, he readily agreed to write a letter in defence of S. L. Joshi, a former student who later became a professor of comparative religion at Dartmouth College but whose involvement in support societies directed at Indian students in the United States in the early 1900s had been deemed 'seditious' by Scotland Yard. Seligman confidently assured recipients of his letter that, having often discussed political matters with Joshi, he thought that his student had always been a 'very sensible fellow, thoroughly aware of the great civilizing work which Great Britain is accomplishing in India, and in no way tainted with anything which by the

52 ERASP, box 8, Hans Goldschmidt to Seligman, 27 July 1921.

53 ERASP, box 7, C. Kukwei Chang to Seligman, 19 May 1919; ERASP, box 36, Seligman to Franck D. Fackenthal, 28 April 1921; ERASP, box 24, Seligman to P. W. Kuo, 23 May 1930, box 24.

54 ERASP, box 5A, José Richling, Consul General of Uruguay, to Seligman, 21 June 1916.

55 Tamotsu Nishizawa, 'The emergence of the economic science in Japan and the evolution of textbooks, 1860s1930s', in Massimo M. Augello and Marco E. L. Guidi, eds., The economic reader: textbooks, manuals and the dissemination of the economic sciences during the nineteenth and early twentieth centuries, London: Routledge, 2012, pp. 309-10.

56 ERASP, box 4, Masao Kambe to Seligman, 18 April 1907; ERASP, box 3, Yetaro Kinosita to Seligman, 12 July 1903; ERASP, box 3, letter from Zensaku Sano to Seligman; John T. Swift, 'Business education in Japan', Asia: Journal of the American Asiatic Association, 17, 1917, pp. 128-31; Yetaro Kinosita, The past and present of Japanese commerce, New York: Columbia University, 1902.

57 ERASP, Carl S. Shoup to E. R. A. Seligman, 4 January 1937, cited in Brownlee, Ide, and Fukagai, Political economy, p. 47; Matsushita Shutaro, The economic effects of public debt, New York: Columbia University, 1929. 
greatest stretch of imagination could be tortured into anything resembling "seditious utterances", 58 Similarly, in May 1914, Seligman wrote to J. M. Keynes to intercede with the India Office in favour of another of his students, Prabhakar Shilotri. ${ }^{59}$

Seligman's capacity to provide pastoral support became even more pronounced in the interwar period. For example, the Indian nationalist Benoy Kumar Sarkar's lectureship at Columbia was greatly facilitated by Seligman. ${ }^{60}$ Even after his departure from New York and while travelling in France, Germany, Italy and Switzerland, the itinerant Sarkar continued to request letters of introduction and advice from his American mentor. ${ }^{61} \mathrm{~B}$. R. Ambedkar, chairman of the committee appointed to draft a constitution for independent India, and Lajpat Rai, an Indian Punjabi author also known as one of the main leaders of the Indian independence movement, were among Seligman's advisees. Seligman referred to Ambedkar as one his 'favorite pupils', while Lajpat Rai was considered to have been one of the Seligmans' 'closest house friends' during his sojourn in America. ${ }^{62}$

\section{'Fiscal reconstruction' in colonial India}

Seligman's Indian students wrote their most interesting pieces during and after the First World War. The necessities of post-war 'fiscal reconstruction' compelled them to think about the incidence of taxation, the inequities of the land and salt taxes, the superiority of direct taxes over indirect taxes, and fiscal interrelations between federal, provincial, and local government levels. The first notable study was Lajpat Rai's 1917 England's debt to India: a historical narrative of Britain's fiscal policy in India. Its focus on the economic rather than the political effects of British rule in India made it a companion to Young India, which had been published a year earlier. ${ }^{63}$ The book owed much to Dadabhai Naoroji's Poverty of India and the 'drain theory' popular among Indian economists at the time. ${ }^{64}$ The first chapters were indeed concerned with the British economic exploitation of India but the last seven exposed the inadequacies of the land revenue system, the burden of taxation, and what Rai thought was a rather poor management of expenditures. The land tax and the salt tax were his main target, as he called for their thorough revision in order to alleviate wealth inequalities. 'It is futile', he wrote, 'for Indians or English to talk of India's economic development until she is free to lay down her own fiscal policy in her own interests. ${ }^{65}$

In his 1920 dissertation about income tax, Shankar Madhav Pagar also thought that this modern form of taxation would receive 'proper consideration' only when 'the consummation of a democratic empire is achieved' ${ }^{66}$ This link between modern taxation and democracy

58 ERASP, box 4, letter of support for S. L. Joshi, 5 July 1909.

59 ERASP, box C18, Seligman to J. M. Keynes, 22 May 1914.

60 Manu Goswami, 'Imaginary futures and colonial internationalisms', American Historical Review, 2012, 117, 5, p. 1482.

61 ERASP, box 8, Benoy Kumar Sarkar to Seligman, Paris, 19 November 1920; Sarkar to Seligman, Paris, 17 June 1921; Sarkar to Seligman, Berlin, 13 November 1921.

62 ERASP, box 24, Seligman to Feror Chaud, 11 January 1929.

63 Lala Lajpat Rai, England's debt to India: a historical narrative of Britain's fiscal policy in India, New York: B. W. Huebsch, 1917, p. i; Lala Lajpat Rai, Young India: an interpretation and a history of the nationalist movement from within, New York: B.W. Huebsch, 1916.

64 Manu Goswami, Producing India: from colonial economy to national space, Chicago, IL: University of Chicago Press, 2004, pp. 224-6.

65 Rai, England's debt to India, p. 329.

66 Pagar, Indian income tax, p. 209. 
found a very clear expression in B. R. Ambedkar's 1925 Columbia dissertation on 'Provincial finance in British India'. In this work, Ambedkar not only studied the evolution of financial and political decentralization in India. He also condemned the remaining fiscal injustices in India and harshly criticized the 1919 Government Act. The 'masses' were still taxed too much relative to the exempted 'classes', and political structures had to be changed promptly in order to ensure fiscal justice. ${ }^{67}$ The land tax and the salt tax were also the object of Ambedkar's ire but his indictment of taxation under colonial rule was one component of a more ambitious critique of the Government of India. Its incapacity to 'venture to tax the tea planters' was just as bad as its incapacity to 'abolish the caste system, prescribe monogamy, alter the laws of succession' or 'legalize intermarriage'. Indeed, because 'progress involved interference with the existing code of social life' and because 'interference is likely to cause resistance', proper tax reform was not likely to happen until the government 'is of the people'. ${ }^{68}$ Ambedkar was then already on the path to becoming one of India's most radical thinkers and a leader of the Dalit movement, calling for the 'annihilation' of the caste system and the advent of an equal society. ${ }^{69}$

Another of Seligman's correspondents, Gyan Chand, also noted that 'the new impulses of national life' were 'trying to express themselves' through 'the financial system' of India and that modern taxation was to serve as an emancipatory tool. ${ }^{70}$ In fact, 'fiscal questions' had to be asked 'from the point of view of the future'. ${ }^{71}$ Citing 'the words of Professor Seligman', Chand wanted to convince fellow Indians that they should no longer regard taxation as a 'burden to be exacted from the unwilling victim, but as a contribution cheerfully rendered by those who are alive to the sense of collective responsibility implicit in the very conception of democracy'. ${ }^{72}$ The system did not necessarily have to be changed completely; what mattered was a radical 'change in the purposes or purpose which the system is intended to fulfill'. ${ }^{73}$ Most importantly, 'national dividend' was to be directed from 'individual to collective channels' and this sense of collective good was really the prerequisite for responsible fiscal citizenship. ${ }^{74}$

J. C. Kumarappa, who later became Gandhi's main economic advisor, wrote his 1930 book on Public finance and our poverty after Seligman had advised him to do so. ${ }^{75}$ Not unlike Ambedkar, Kumarappa was principally concerned with the unequal incidence of indirect taxation, and linked poverty in India to the government's fiscal policy. Borrowing from Seligman's advocacy of the 'ability to pay' principle, he thought that 'the incidence of taxation should be carefully considered, and [that] the burden should be according to faculty'. He asked for 'those on the borderland of subsistence' to be 'relieved at the cost of those who are blessed with larger shares of worldly goods'. ${ }^{76} \mathrm{He}$ also celebrated the income tax as the only truly modern alternative: 'In all taxation systems, income tax is gaining ground all over the world as

67 B. R. Ambedkar, The evolution of provincial finance in British India, London: P. S. King, 1925, p. 192.

68 Ibid., p. 196.

69 See, for instance, B. R. Ambedkar, Annihilation of caste: the annotated critical edition, London: Verso, 2016.

70 Chand, Financial system of India, 1926, p. 13.

71 Chand, Fiscal reconstruction, 1928, p. vi.

72 Ibid., pp. 18, 19.

73 Ibid., p. 12.

74 Ibid., p. 23.

75 See the reference to Seligman in the preface to Joseph Cornelius Kumarappa, Public finance and our poverty: the contribution of public finance to the present economic state of India, Ahmedabad: Navajivan Press, 1930, p. ix; see also Mark Lindley, J. C. Kumarappa: Mahatma Gandhi's economist, Mumbai: Popular Prakashan, 2007, p. 15.

76 Kumarappa, Public finance and our poverty, p. 3. 
the most satisfactory amongst taxes. ${ }^{77}$ Elites were still escaping just and progressive taxation, such as those 'large landlords who merely pay the land revenue assessment, which works out as a proportional tax'. ${ }^{78}$ Published in 1930, the year of the Salt March in India, Kumarappa's book shared Ambedkar's view on land and salt taxes. Kumarappa thought that the latter was nothing but 'an unqualified evil bringing ruin to the nation, not only fiscally but also socially' ${ }^{79}$

In fact, quite a significant number of public finance works published in India during the interwar period made either direct or indirect references to Seligman's work. In his 1931 volume on The taxation of income in India, the economist V. K. R. V. Rao, a prominent Indian economist and founder of the Delhi School of Economics in 1949, respectfully referred to Seligman in his discussion of the taxation of income in India by celebrating 'Professor Seligman' for providing 'the first and probably the best exposition and popularization of the principles underlying the income-tax' ${ }^{80}$ Pramathanath Banerjea, the author of A bistory of Indian taxation in 1930, cited Seligman alongside British economists such as Arthur Pigou. ${ }^{81}$ Seligman also kept close ties with Findlay Shirras, a British professor in Bombay who was a specialist in colonial Indian public finance. Shirras regularly kept Seligman abreast of fiscal developments in India, for example by sending him the report of the Tax Commission of India or simply by informing him of political debates. ${ }^{82}$

British liberal imperialists such as the economist Vera Anstey understood the potential dangers of such an approach and deemed Seligman-inspired tax reform plans utterly 'unrealistic' and overly 'ambitious'. ${ }^{83}$ Yet the idea that modern taxes should be more closely adjusted to the personal capacity of the taxpayer and that regressive indirect taxes should be increasingly shunned was powerfully etched in the minds of Seligman's students. An intriguing case is Mustapha Khan Fateh, a Persian student who wrote his $\mathrm{PhD}$ dissertation on 'The economic position of Persia' under the supervision of Seligman, as well as short articles on taxation in Persia. ${ }^{84}$ After having left New York in early 1919, Fateh arrived in France and in July wrote Seligman a letter complaining about the cost of living in post-war Paris but also about the general backwardness of the tax system. He described a generally depressed economic life where 'there are as many taxes on consumption as there are articles for consumption' and where 'everything is taxed in a uniform way'. 'Their income tax' he wrote, 'though started recently, has not worked well yet, and many have evaded it ... The burden is on the consumers ... The protectionists are very strong here, and one wonders as if one is not living in a nineteenth century France rather than at present $[$ sic $]$. 85

77 Ibid., p. 34.

78 Ibid., p. 35.

79 Ibid., pp. 36-7.

80 V. K. R. V. Rao, Taxation of income in India, Calcutta: Longmans, Green and Co., 1931, p. xiv.

81 Pramathanath Banerjea, A history of Indian taxation, Calcutta: Macmillan and Co., 1930.

82 ERASP, box 24, Seligman to G. Findlay Shirras, 25 June 1926.

83 Vera Anstey, 'Reviewed works: The Indian public debt by D. L. Dubey; The evolution of the Indian income tax by J. P. Niyogi; The essentials of federal finance by Gyan Chand; Present-day banking in India by B. R. Rau; Population problem of India by B. T. Ranadive; The Indian cotton textile industry by M. P. Gandhi', Economica, 33, 1931, pp. 351-7, cited in Marie Scot, 'Faire école: les alumni universitaires indiens de la London School of Economics', Histoire@Politique: revue du centre d'histoire de Sciences Po, 15, 2011, p. 17.

84 Mustafa Kahn Fateh, The economic position of Persia, London: P. S. King \& Son, 1926.

85 ERASP, box 7, Mustapha Khan Fateh to Seligman, 18 July 1919. 


\section{A Chinese road to fiscal freedom}

Seligman's Chinese students shared many of the concerns and aspirations of their Persian and Indian counterparts in regard to their respective countries, namely chronic foreign indebtedness and a yearning for greater fiscal autonomy. In the case of China, however, the adaptability of Chinese fiscal principles to modern Western standards was of utmost importance. ${ }^{86}$ As early as 1911, Seligman had a student who wrote a dissertation on the 'Economics principles of Confucius and his school'. In this work, Chen Huanchang was eager to notice that Confucius' writings on taxation were remarkably similar to Seligman's and that the norms of modern public finance, such as the principle of the ability to pay or the link between representation and taxation, could also be found in early Chinese writings. ${ }^{87}$ Furthermore, he remarked that Seligman's teleological reading of fiscal history in his Essays on taxation found clear echoes in ancient Chinese fiscal theory. ${ }^{88}$

Historians have written about John Dewey and his work with Chinese scholars at Columbia. ${ }^{89}$ However, there were also 'many able students of fiscal affairs among the young Chinese that throng the halls of Columbia' working under Seligman's guidance. ${ }^{90}$ In 1914, Chen Zhao Kun's overview of the system of taxation in the Ching dynasty was published in Studies in History, Economics, and Public Law, a series edited by Columbia University's Faculty of Political Science. Many more would follow. The same year, Ma Yinchu, best known as the father of Chinese family planning, published his doctoral dissertation on the finances of the city of New York, claiming that 'the finances of the Empire City of New York and those of the Empire Republic of China have many points of resemblance'. ${ }^{91}$ Ma was primarily interested in New York's capacity to pass from 'financial chaos into a financial system'. ${ }^{92}$ The study was divided into four parts, covering scientific budget-making, the system of taxation, administration of the city debt, and 'the control of revenues and expenditures under the new system of accounting, 93

A year later, $\mathrm{Xu} \mathrm{Xi}$ wrote on 'railway problems' in China, focusing specifically on the question of railway bonds and China's foreign debt. ${ }^{94}$ In 1916 , Jin Zhu wrote more broadly on the 'tariff problem in China' and compared China to Japan in earlier times, advocating greater control of customs and tariffs. ${ }^{95}$ Yet another Chinese student of Seligman, Huang Hianliang, published his dissertation, 'The land tax in China', in 1918, which sought to apply modern

86 Zou Jinwen, 'The development of early modern Chinese economics: based on investigation of doctoral dissertations by Chinese students studying abroad in the late Qing and Republican periods', Social Sciences in China, 33, 2, 2012, pp. 75-93.

87 Chen Huanchang (Huan-Chang Chen), The economic principles of Confucius and his school, New York: Columbia University, 1911, p. 623.

88 Ibid., p. 622.

89 See, for example, Jessica Ching-Sze Wang, John Dewey in China: to teach and to learn, Albany, NY: State University of New York Press, 2007; Stacy Bieler, Patriots or traitors: a history of American-educated Chinese students, London: Routledge, 2003.

90 Seligman, preface to Shou, Democracy and finance in China, pp. 7-8.

91 Chen Zhao Kun (Shao Kwan Chen), The system of taxation in China in the Tsing dynasty, 1644-1911, New York: Columbia University, 1914; Ma Yinchu (Yin-Chu Ma), Finances of the city of New York, New York: Columbia University, 1914, p. 5.

92 Ma, Finances of the city of New York, p. 5.

93 Ibid., p. 6.

94 Xu Xi (Mongton Chih Hsu), Railway problems in China, New York: Columbia University, 1915.

95 Jin Zhu (Chu Chin), The tariff problem in China, New York: Columbia University, 1916, p. 17. 
land tax practices to the Chinese context. According to him, a proper land tax reform would require the creation of a bureau of land measurement, the compilation of a tax roll, and the creation of a 'separate machinery of administration'. ${ }^{96}$ In 1919, it was Huang Fenghua's turn to publish his Columbia dissertation, on public debts in China, in which he lamented the challenges wrought by China's 'foreign indebtedness'. What, he asked, were 'the prerequisites in order to borrow advantageously?' They entailed a firmer control over the country's finance, tax reform, and 'honest and official officialdom'. ${ }^{97}$ In the same year, Shi Zongshu sought to offer a vision of China's future economic 'potentialities' after centuries of fiscal subjection and undue exemptions granted to foreigners. ${ }^{98}$ In 1922, Seligman himself authored an article entitled 'Some economic problems of China' in the Chinese Students' Monthly, urging Chinese students to reform 'economic life' through a thorough overhaul of the current public finance system. ${ }^{99}$

Li Quanshi's 1922 dissertation specifically dealt with the coordination of central and local finance, since China was still entangled in political turmoil. ${ }^{100}$ Praising Seligman's 'constant guidance, encouragement, inspiration, and sound teaching', Li nevertheless saw a different role for the Chinese state. ${ }^{101}$ 'Influenced by the wave of democracy throughout the whole world', China would have to opt for 'local self-government' in order to break with a past of overly centralized statism. ${ }^{102}$ As he remarked, 'with constitutionalism came the issue of local selfgovernment, and with local self-government came the question of the separation of local finance from the national finances'. ${ }^{103}$ Citing Harold Laski and Franz Oppenheimer on the state, Li Quanshi stressed that local self-government was the only way to restore 'popular control of the purse'. ${ }^{104}$ The idea was eventually for China to become 'one of the most prosperous, the most progressive, and the most liberal and democratic powers in the world' ${ }^{105}$

Local self-government was indeed the 'quintessence of liberalism' and in line with what the 'leading countries' were doing. ${ }^{106}$ Furthermore, China could learn from America and Canada because of their size: in such large countries, there could be no 'efficient working of a centralized and bureaucratic system of administration'. ${ }^{107}$ Citing Seligman, Li suggested that indirect taxes should accrue to the national budget, while direct taxes should feed local budgets. ${ }^{108}$ In America and Europe, income and inheritance taxes were increasingly centralized but China had to take a slightly different route. The main difference between China and the rest of the world was that there was no Chinese trend towards 'the extension of governmental functions'. People and their 'initiative, energy, and intelligence' had to be given priority over

96 Huang Hianliang (Han-Liang Huang), The land tax in China, New York: Columbia University, 1918 , p. 15.

97 Huang Fenghua (Feng-Hua Huang), Public debts in China, New York: Columbia University, 1919, p. 90.

98 Shi Zongshu (Chong-Su See), The foreign trade of China, New York: Columbia University, 1919, pp. 8, 356-7.

99 E. R. A. Seligman, 'Some economic problems of China', Chinese Students' Monthly, 18, 2-3, pp. 11-14.

$100 \mathrm{Li}$ Quanshi (Chuan Shih Li), Central and local finance in China: a study of the fiscal relations between the central, the provincial, and the local governments, New York: Columbia University, 1922; Hans Van de Ven, 'Public finance and the rise of warlordism', Modern Asian Studies, 30, 4, 1996, pp. 829-68. $\mathrm{Li}$, Central and local finance in China, p. 8.

102 Ibid., p. 69.

103 Ibid., p. 70.

104 Ibid., p. 84.

105 Ibid., p. 84.

106 Ibid., pp. 137, 92.

107 Ibid., p. 138.

108 Ibid., pp. 151-2. 
'benevolent despotism' from above. And, fundamentally, only sound local finance could enable this. ${ }^{109}$

In 1924, the focus reverted to external tariffs, as a student of Seligman named Pan Xulun published a dissertation on the trade relationship of the US with China. The book was enthusiastically prefaced by Seligman and Jeremiah Jenks, an old colleague of Seligman and director of the 'Division of Oriental Commerce and Politics' at New York University. A prosperous and advanced civilization such as China would eventually catch up with the United States, Seligman wrote. However, the two countries would first have to 'work out a cooperation that would not be to the detriment of the sovereignty of China'. ${ }^{110}$ Ensuring the 'safety' of foreign capital would no longer mean endless fiscal subjection and humiliation. The intellectual and scholarly collaboration signalled in the book's very origins should be replicated at a much larger scale in order to ensure 'independent, fair cooperation for mutual interests' ${ }^{111}$

Among all these public finance dissertations, one study received particular praise from Seligman. Indeed, in his preface to Shou Jingwei's sophisticated critique of China's fiscal situation, Seligman expressed his admiration for Shou's 'intimate acquaintance with all that is best in the modern fiscal science of Europe' but also his capacity to shed light on little-known Chinese fiscal theories and practice. ${ }^{112}$ China's taxation powers had to be liberated and become more democratic. A new 'system of fiscal philosophy or ideology' thus had to be created through the harmonization of 'the fiscal ethics, the fiscal psychology and the fiscal sociology of the Chinese people, taking into account Chinese philosophy, history and presentday conditions'. ${ }^{113}$ According to Shou, China was ready for fiscal change. Old 'harmful' forms of taxation such as the salt tax or the likin (an internal customs duty) should be abolished in favour of 'the imposition of direct taxation in the form of an income tax or an inheritance tax'. ${ }^{114}$ In his chapter on the 'principles of fiscal reconstruction', Shou specifically referred to Seligman's contention that 'in democratic communities, where legislation is influenced by the mass of the people, we commonly discern a tendency to oppose indirect taxes'. ${ }^{115}$

Not unlike Chand in India, Shou's main aim was to explain the importance of political participation in fiscal issues. Both were intimately linked as 'China [was] ready for a modern democratic system of finance, without which no democratic government is possible. ${ }^{116}$ His fiscal reading of political history allowed him to explain that the republican regime was going in the right direction despite the current fiscal chaos. ${ }^{117}$ In order to achieve 'fiscal autonomy instead of fiscal restriction', 'civil control as opposed to military control over the fiscal machinery', 'finance by taxation instead of finance by loans', and 'direct' rather than 'indirect taxation', a number of ethical, economic, sociological, regional, political, administrative, and even psychological reforms had to be achieved. ${ }^{118}$ These entailed recognizing the 'family' as a fiscal unit, giving more power to local authorities, providing the means to avoid double

109 Ibid., p. 153.

110 Pan Xulun (Su Lu Pan), The trade of the United States with China, New York: China Trade Bureau Inc., 1924, p. 356.

111 Ibid., p. xiii.

112 Seligman, preface to Shou, Democracy and finance in China, p. i.

113 Shou, Democracy and finance in China, p. 9.

114 Ibid., p. 47.

115 Ibid., p. 133.

116 Ibid., p. 48.

117 Ibid., pp. 162-3.

118 Ibid., pp. 171-80. 
taxation within China, installing an 'honest' and 'efficient' fiscal administration, and changing the 'fiscal psychology' of the Chinese. Taxation had to be understood as more than a mere tribute; it was a tool that the people could use to govern themselves. Finally, if tax policies were to be willingly accepted by the people, illicit taxation had to be fought very energetically. ${ }^{119}$

Finance by the people thus had to be firmly based on 'scientific accounting'. Indeed, the budget was 'not mere arithmetic' but 'an expression of the will of the government as well as that of the people', as it showed the 'working capacity of the body politic'. ${ }^{120}$ This 'effective control of the budget with enlightened opinion' would lead to greater welfare and 'social amelioration'. That was, according to Shou via Seligman, the ultimate aim of a modern system of taxation. ${ }^{121}$ Direct taxes were to be levied on the basis of income and would eventually lead to the 'gradual reduction and eventual abolition of consumption taxes on the necessities of life'. In fact, further economic development was believed to 'permit the introduction of better forms of taxation'. ${ }^{122}$ Duan Maolan and Mai Jianzeng thought that they could perhaps find it in the economic thought of Simonde de Sismondi or the 'fiscal policies of Albert Gallatin', but many found it already germinating in China. ${ }^{123}$

\section{A new fiscal order for the American empire}

While Seligman's engagement with Western imperialism in China or India was only indirect, he dealt much more straightforwardly with places where American economic and political influence was extensive. Cuba proved to be an ideal testing ground for his fiscal ideas. In 1931, Seligman and his assistant Carl S. Shoup began working on their report on the Cuban tax system with the aim of making it more equitable and efficient through 'modernization' according to 'scientific' principles. Yet, while advocating a more 'democratic' tax system, Seligman refrained from making comments on Gerardo Machado's authoritarian regime. The two economists restricted themselves to the examination of current deficiencies and simply sought to propose a 'firm foundation' upon which a new tax system could be built. ${ }^{124}$ Called 'El Plan Seligman' by the Cubans, the 426-page-long detailed report carried two proposals. The boldest was 'Proposal 1', which anticipated that Machado's Public Works loan could be reworked and recommended the abolition of the lottery tax, the sales tax, and most stamp taxes. A centralized tax on real estate and a 'presumptive personal income tax' would also be put in place. ${ }^{125}$ 'Plan 2' remained much more in line with the demands of Wall Street and the necessities of debt servicing. ${ }^{126}$

The report showed remarkable awareness of the practical difficulties of tax reform in a non-Western country. The authors knew that the Cuban system was still informed by the

119 Ibid., pp. 179-80.

120 Ibid., p. 186.

121 Ibid., p. 194.

122 Ibid., p. 182, emphasis added.

123 Duan Maolan (Mao-Lan Tuan) Simonde de Sismondi as an economist, New York: Columbia University, 1927; Mai Jianzeng (Chien-Tseng Mai), The fiscal policies of Albert Gallatin, New York: Columbia University, 1930, p. 144.

124 'Seligman outlines new Cuban tax code', New York Times, 13 February 1932.

125 E. R. A. Seligman and Carl S. Shoup, A report on the revenue system of Cuba, Havana: Talleres tipographicos de Carasa, 1932, p. 22.

126 Michael R. Adamson, 'The Shoup missions to Cuba', in Brownlee, Ide, and Fukagai, Political economy, p. 86. 
Spanish colonial system and that direct taxes could only be introduced slowly. Import duties were to be retained and would still 'form the largest single source of revenue'. ${ }^{127}$ After careful calculations, they recommended that administrative costs be drastically reduced and collection methods modernized. The proliferation of customs houses throughout the country was also to be curtailed in order for a new fiscal order to emerge. The latter would, of course, not appear fully formed. As a reviewer justly remarked, 'the proposal is made for a tropical country with a native population hitherto taxed almost entirely by indirect taxes collected mainly from business firms'. ${ }^{128}$ The revenue administration was to be thoroughly reformed: 'privately-paid employees' had to be abolished and the revenue administration thoroughly depoliticized. ${ }^{129}$ Although the plan was certainly 'a counsel of perfection', some variant of the programme might still 'be of benefit to every civilised community'. 130

In US overseas territories and nominally independent countries under US financial control, the first task was to dismantle the particularly unsound Spanish colonial system. Americans had started by abolishing the consumo taxes when they arrived in Cuba, the Philippines, and Puerto Rico, but more could be done. ${ }^{131}$ Seligman's students from these countries who were seeking to understand power structures in the world economy were thus urged to inquire into the nature of Spanish economic imperialism. Heeding Seligman's suggestion, Andrès V. Castillo, who would later become Governor General of the Philippines Central Bank, wrote a much remarked upon $\mathrm{PhD}$ thesis on Spanish mercantilism in 1930. ${ }^{132}$ Drawing clear links between Spanish economic imperialism in the seventeenth and eighteenth centuries and 'the economic policies of the empires of today', he made explicit references to the policies of the British in India, the Dutch in the East Indies, and the Americans in the Philippines.

The 1930s were an era of mounting imperial protectionism and Castillo observed that 'present day tariff discussions only improve upon the theories of the mercantilists but do not differ from them'. ${ }^{133}$ This new form of mercantilism, which assigned colonies to the exclusive service of metropoles, condemned the non-Western world to economic inequality with the West, a feature of the late interwar world economy that Seligman also openly criticized. At the very moment when he would have been proofreading Castillo's dissertation, he was declaring at the Academy of Political Science annual meeting that 'the time is past when each country expects to raise itself upon the prostrate form of its neighbour, and to monopolize either the control of raw materials or the disposal of finished products'. ${ }^{134}$

127 Seligman and Shoup, Report on the revenue system of Cuba, p. 96.

128 Simon E. Leland, review of 'E. R. A. Seligman and Carl. S. Shoup, A report on the revenue system of Cuba', Journal of Political Economy, 42, 5, 1934, p. 689.

129 'Would bar politics from Cuban finance: Dr. Seligman suggests reforms for fiscal system of the island', New York Times, 28 February 1932.

130 Seligman and Shoup, Report on the revenue system of Cuba, pp. 111-12.

131 E. R. A. Seligman, 'Tax reduction and tax exemption', North American Review, 219, 819, 1924, p. 444. See also ERASP, box 24, Seligman to Benvenuto Griziotti, 23 April 1930. Consumo taxes were internal excise taxes levied on essential goods under Spanish colonial rule.

132 ERASP, box 24, Seligman to Andres V. Castillo, 7 January 1931.

133 Andres V. Castillo, Spanish mercantilism: Gerónimo de Uztáriz - economist, New York: Columbia University, 1930, p. 178.

134 Seligman, 'World peace and economic stability', p. 203. 


\section{World peace, fiscal convergence, and the challenges of international fiscal cooperation}

The vision of a new global fiscal order shared by Seligman and his students needs to be placed within the broader history of his internationalist pursuits during the interwar years. During this time, the international aspects of fiscal questions posed particularly important questions. Shou, for instance, saw a clear link between international peace, the end of war, and 'the fiscal conditions of nations'. Indeed, he wrote that 'We may call this the fiscal normality of a nation as well as the whole world.' Peace could only be durably achieved if countries were fiscally equal and used similar fiscal systems. ${ }^{135}$ Although non-Western scholars were not included in official discussions about fiscal cooperation in the 1920s, they read Seligman's work on the subject and approvingly cited his affirmation that fiscal cooperation would bring about 'an era of world peace, and of world progress'. ${ }^{136}$ Fiscal cooperation would first be enacted through treaties, of course, but, in the long term, the convergence of tax systems seemed more crucial.

Seligman's role in fostering research about the evolution of economic and fiscal practices in Europe and the non-Western world made him acutely conscious of the challenges that these fiscal innovations could pose at an international level. As early as 1895 , Seligman presciently remarked that 'Today not only does the same capitalist invest in different enterprises, not only is the producer often dependent for a part of his capital on sums that belong to others, but the old geographical unity has been dissolved, and there is no necessary connection between the residence of the capitalist and the place where his capital is employed.' This had clear consequences for national taxation systems, which 'may now be entirely inadequate because of the failure of government to take account of these new complications in property rights'. ${ }^{137}$ Needless to say, this inadequacy only became more problematic when tax burdens began to soar dramatically in the aftermath of the war.

In 1924, Seligman published an article in which he attempted to calculate the comparative evolution of tax burdens in the twentieth century despite glaring practical difficulties, notably the variance in fiscal years. He noted that direct taxes on wealth had increased spectacularly and that 'the burden had now become a crushing one' thanks to a 'scale of graduation never attained before', an observation confirmed by recent research on the impact of the First World War on tax burdens. ${ }^{138}$ Indeed, in 1919 , the United States was applying a rate of $77 \%$ on top incomes while rates in Great Britain and France spiked to $60 \%$ or more. These rises were utterly unprecedented given that, before the war, rates had never attained more than $10 \% .{ }^{139}$ Rates differed across countries but so did ways of calculating income, profits, and wealth. The result was 'fiscal chaos' with 'every year of increasing international life'. ${ }^{140}$ Yet, powerful forces were at play, in the non-Western world as well, in order to 'normalize' tax systems.

Shou, Democracy and finance in China, pp. 190-1.

Gyan Chand, review of E. R. A. Seligman's Double taxation and international fiscal cooperation being a series of lectures delivered at the Academie de droit international de la Haye, New York: Macmillan and Co., 1928 , in Indian Journal of Economics, 11, 1931, pp. 725-6.

Seligman, Essays in taxation, 2nd edn, New York and London: Macmillan and Co., 1897, pp. 95-6.

8 E. R. A. Seligman, 'Comparative tax burdens in the twentieth century', Political Science Quarterly, 39, 1, 1924, p. 16. For figures, see Thomas Piketty, Capital in the twenty-first century, Cambridge, MA: Harvard University Press, 2014.

Piketty, Capital, pp. 498-500.

E. R. A. Seligman, Double taxation and international fiscal cooperation being a series of lectures delivered at the Academie de droit international de la Haye, New York: Macmillan and Co., 1928, p. 31. 
Taxation naturally grew into an important concern of international economic governance, whose new locus became the League of Nations. ${ }^{141}$ During the seventh meeting of the Finance Section of the Provisional Economic and Financial Committee of the League of Nations, which took place in Geneva on 30 May 1921, members began their reunion by discussing the question of double taxation - that is, the levying of tax by two or more jurisdictions on the same declared income. This had arisen as a particularly thorny issue at the turn of the century, as income and capital ownership became much more complex and differentiated. When the idea of appointing an impartial international commission of economists whose task would be to 'collect salient facts relating to the question; point out the economic consequences of double taxation and perhaps, suggest action' was brought to the table, the name of Seligman sprang up quite spontaneously. ${ }^{142}$ Seligman was eventually nominated along with three other scholars, with whom he hammered out the general principles governing international competence in taxation and proposed concrete measures. Important principles were articulated in the final report, namely that taxes should be paid to the source government.

This idea was Seligman's brainchild: according to him, in matters of taxation 'economic allegiance' weighed more heavily than 'political allegiance'. Indeed, given the complexities of modern international economic life, he thought that fiscal obligation was better tied to the site of economic activity than citizenship. As he said during his public lectures on international fiscal cooperation: 'While the foreigner still retains in many respects his importance from the political point of view, he has lost his importance from the economic standpoint. We are, today, either directly or indirectly citizens of a world economy. ${ }^{143}$ As a result, Seligman became a proponent of a more systematic exchange of information on taxation and even dared to wish for a greater convergence of tax systems. He was convinced that economic issues had to be resolved on an international level. In 1932, he called for the advent of a 'positive Adam Smith' who would point to the 'real meaning' of 'The Wealth of Nations' as a 'unified concept'. ${ }^{144}$ In the troubled years of the interwar period, Seligman thought that it was irresponsible to think only 'in terms of national management' and demanded the transcendence of local and national efforts.

This international outlook found a clear expression in his intense internationalist commitments during the interwar period. Although Kuehl and Dunn do not refer to Seligman, he was an eminent internationalist and served for some time as the vice-president of the NonPartisan League of Nations Association. ${ }^{145}$ In the early 1920 s, he made various trips to Geneva, which seemed to have left a lasting mark on him. ${ }^{146}$ When not in Switzerland, he received regular updates from Americans appointed to the League, and novices sent him requests for letters of introduction to the Geneva institutions. Beside tax issues, Seligman was also involved

141 Patricia Clavin, Securing the world economy: the reinvention of the League of Nations, 1920-1946, Oxford: Oxford University Press, 2013.

142 Sunita Jogarajan, 'Stamp, Seligman and the drafting of the 1923 experts' report on double taxation', World Tax Journal, 5, 3, 2013, p. 372.

143 Seligman, Double taxation, p. 8.

144 E. R. A. Seligman, 'The breakdown in world trade', Proceedings of the Academy of Political Science, 15, 1, 1932, p. 4, cited in Ann Mumford, 'E. R. A Seligman: the surprising fiscal sociologist', in John Tiley, Studies in the history of tax law, vol. 5, Oxford: Hart Publishing, 2011, p. 293.

145 See Warren F. Kuehl and Lynne K. Dunn, Keeping the covenant: American internationalists and the League of Nations, 1920-1939, Kent, OH: Kent State University Press, 1997.

146 Seligman's impressions of the League and of the 'Geneva spirit' more generally are presented in his 1924 speech given at the American Ethical Union, in E. R. A. Seligman, The League of Nations, New York: American Ethical Union, 1924. 
in questions of labour and maintained a correspondence with Albert Thomas, the head of the International Labour Organization from 1919 to $1932 .{ }^{147}$ Although he only rarely paid attention to colonial fiscal systems in Africa, in 1924 he nevertheless urged William Rappard, then director of the Mandates' section at the League, to pay attention to 'plans for an investigation into social conditions into the Portuguese colonies in Africa' proposed by the University of Wisconsin sociologist and professor Edward Ross. ${ }^{148}$

Many of Seligman's internationalist pursuits were not directly linked to economic matters: he also became actively involved in a number of eclectic initiatives in the United States, such as the American Cooperative Committee of the Pan-European Union, the League of Neighbours, and the Union of East and West, the latter two initiated by Charles Frederick Weller and Kedar Nath Das Gupta respectively. ${ }^{149}$ Seligman received dinner invitations in honour of Annie Besant, read Indian spiritualist journals, and attended the 'First India Conference' in New York in 1928. In fact, throughout the 1920s he was approached by world peace activists of all sorts who were interested in his expertise on taxation or simply in his internationalist commitments. These commitments culminated in Seligman's final grand oeuvre, the Encyclopaedia of the social sciences, which serves as an impressive testimony to his deep belief that social science could and should serve a public purpose. ${ }^{150}$

\section{Conclusion: reappraising Seligman's role within the 'early Columbia school of taxation and development'}

The universalizing nature of the infrastructures of Western knowledge in a world shaped by Western imperialism gave a special salience to Seligman's message on taxation and modernity. A considerable number of his non-Western students absorbed the message and began to reflect on their own fiscal futures. Some even went on to play crucial roles in their country's fight for independence, and suggested radical change. According to Lajpat Rai, Ambedkar, and Kumarappa, the tax system crystallized many of the evils of colonialism, and public finance reform could provide immediate solutions to the political and economic subjection of India. In China, fiscal issues formed an integral part of nationalist politics. According to the Chinese scholars who worked with Seligman, greater fiscal accountability would be attained through popular consent. Democratic and fiscal reforms were in fact one and the same thing.

Seligman's exchanges with a wide array of public finance specialists outside the United States allowed radical ideas to emerge, although he never published any important work on the question himself. Yet this still made him an active member of the so-called 'Columbia school of taxation and development', rather than just an early precursor, as Mehrotra contends. ${ }^{151}$ Seligman occupied a central position in a large and multifaceted transnational sphere of expertise on progressive taxation, and his teleological reading of the history of taxation led to the formulation of a powerful doctrine linking taxation to development. He was able to

147 ERASP, box 12, Albert Thomas to Seligman, April 1924.

148 ERASP, box 12, William Rappard to Seligman, 6 June 1924; Edward Alsworth Ross, Report on the employment of native labor in Portuguese Africa, New York: Abbott Press, 1925.

149 Seligman maintained a correspondence with Richard Coudenhove-Kalergi, founding president of the PanEuropean Union.

150 Daniele Besomi, ed., Crises and cycles in economic dictionaries and encyclopaedias, New York: Routledge, 2012.

151 Mehrotra, 'From Seligman to Shoup', p. 37. 
convince his numerous interlocutors that income tax was 'essentially a modern phenomenon' and that modern taxation was intrinsically linked to democratic government. ${ }^{152}$ The First World War only accelerated this broader reflection about the 'the relations between the fiscal systems and the fundamental conditions of economic and social progress'. ${ }^{153}$ The field of 'taxation and development' was set on the road to a bright future. ${ }^{154}$

Madeline Woker is a PhD candidate in history at Columbia University, New York. Her dissertation, 'Empire of inequality: the politics of taxation in the French empire, 1918-1939', examines the fiscal architecture of the French colonial empire and the politics of colonial tax reform during the interwar period. More particularly, it traces how colonial tax policies related to growing anxiety about the political, social, and moral consequences of financial inequality in the French colonial empire.

152 E. R. A. Seligman, 'Income tax', in Encyclopaedia of the social sciences, New York: Macmillan, 1929-34, vol. 7, p. 626.

153 E. R. A. Seligman, 'Public finance', in Encyclopaedia of the social sciences, vol.12, pp. 645-6.

154 Richard Bird, 'Taxation and development: what have we learned from fifty years of research?', International Center for Public Policy working paper 12-02, 2012, http://icepp.gsu.edu/files/2015/03/ispwp1202.pdf (consulted 26 April 2018). 